\title{
FIRST MEDITERRANEAN RECORDS OF SPINETAIL DEVIL RAY, MOBULA JAPANICA (ELASMOBRANCHII: RAJIFORMES: MOBULIDAE)
}

\author{
Christian CAPAPÉ ${ }^{1 *}$, Sihem RAFRAFI-NOUIRA², Olfa EL KAMEL-MOUTALIBI ${ }^{2}$, Moncef \\ BOUMAÏZA ${ }^{2}$, and Christian REYNAUD 3 \\ ${ }^{1}$ Laboratoire d'Ichtyologie, Université Montpellier II, Sciences et Techniques du Languedoc, Montpellier, France \\ ${ }^{2}$ Laboratoire d'Hydrobiologie Littorale et Limnique, Université de Carthage, Faculté des Sciences, Zarzouna, \\ Bizerte, Tunisia \\ ${ }^{3}$ Laboratoire Interdisciplinaire de Recherche sur la Didactique, l'Éducation et la Formation, Faculté d'Éducation, \\ Université Montpellier, Montpellier, France
}

\begin{abstract}
Capapé C., Rafrafi-Nouira S., El Kamel-Moutalibi O., Boumaïza M., Reynaud C. 2015. First Mediterranean records of spinetail devil ray, Mobula japanica (Elasmobranchii: Rajiformes: Mobulidae). Acta Ichthyol. Piscat. 45 (2): 211-215.

Abstract. Captures of 11 spinetail devil rays, Mobula japanica (Müller et Henle, 1841), from the northern coast of Tunisian (central Mediterranean) are reported in the present paper. Of these 11 specimens, five specimens were described. These captures constitute the first records of the species in the Tunisian waters, but also in the Mediterranean Sea, extending its distribution. This unusual occurrence of $M$. japanica is probably due to a migration from the eastern tropical Atlantic into the Mediterranean Sea through the Strait of Gibraltar.
\end{abstract}

Keywords: Chondrichthyes, migration, Tunisian coast, white-tipped dorsal fin, gill filter plates, morphometric measurements

Of the nine recognized species belonging to the genus Mobula Rafinesque, 1810 (see Notarbartolo Di Sciara 1987), only a single species, giant devil ray, Mobula mobular (Bonnaterre, 1788), has hitherto been reported from the Mediterranean Sea (McEachran and Capapé 1984). This species is sporadically caught off southern France (Granier 1964, Capapé et al. 1990) and along the Tunisian coast (Capapé and Zaouali 1976, Bradaï and Capapé 2001). It is, however, rather common off the Algerian coast (Hemida et al. 2002) and in the Adriatic Sea (Bello et al. 2012).

Observations and surveys conducted since 2004 along the northern coast of Tunisia allowed to record elasmobranch species in areas where they were not usually observed such as the Tunis Southern Lagoon (Mejri et al 2004) and the Lagoon of Bizerte (El Kamel et al. 2009). Additionally, our actions were also supported by local divers and fishermen who actively helped us, in reporting sightings and captures of specimens. In the wake of this collaboration, the authors were promptly informed that a devil ray was captured on 23 August 2014 off Cani Rocks
(Fig. 1), and landed at the fishing site of Ras Jebel, a town located $50 \mathrm{~km}$ north of Tunis. The specimen was carefully examined, photographed, measured to the nearest $1 \mathrm{~mm}$, and weighed to the nearest $1 \mathrm{~kg}$. It was a female of 2600 $\mathrm{mm}$ disc width (DW), $1200 \mathrm{~mm}$ disc length, and its eviscerated body mass reached $100 \mathrm{~kg}$ (Fig. 2). The head was recovered and delivered to the laboratory for further examinations. On 24 August 2014, the heads of 3 other specimens caught in the same area were observed. Additionally, on 28 August 2014, a female was captured having 2180 mm DW and weighing $67 \mathrm{~kg}$. In all, 11 specimens were caught by light fishing focusing European pilchard, Sardina pilchardus (Walbaum, 1792), and mackerel Scomber spp., at a depth of $54 \mathrm{~m}$ approximately, by gillnets of $16 \mathrm{~mm}$ mesh size, off Cani Rocks by $37^{\circ} 24^{\prime} 25.76^{\prime \prime} \mathrm{N}$ and $10^{\circ} 10^{\prime} 55.00^{\prime \prime} \mathrm{E}$ (Fig. 1).

The diagnosis was as follows: disc broad, short length measured from mid-snout $44.7 \%-46.2 \%$ in disc width, anterior margins of pectoral slightly convex, posterior concave, angles acute, rounded at apex, head very short, distance from tip of cephalic lobes to fifth gill slit 


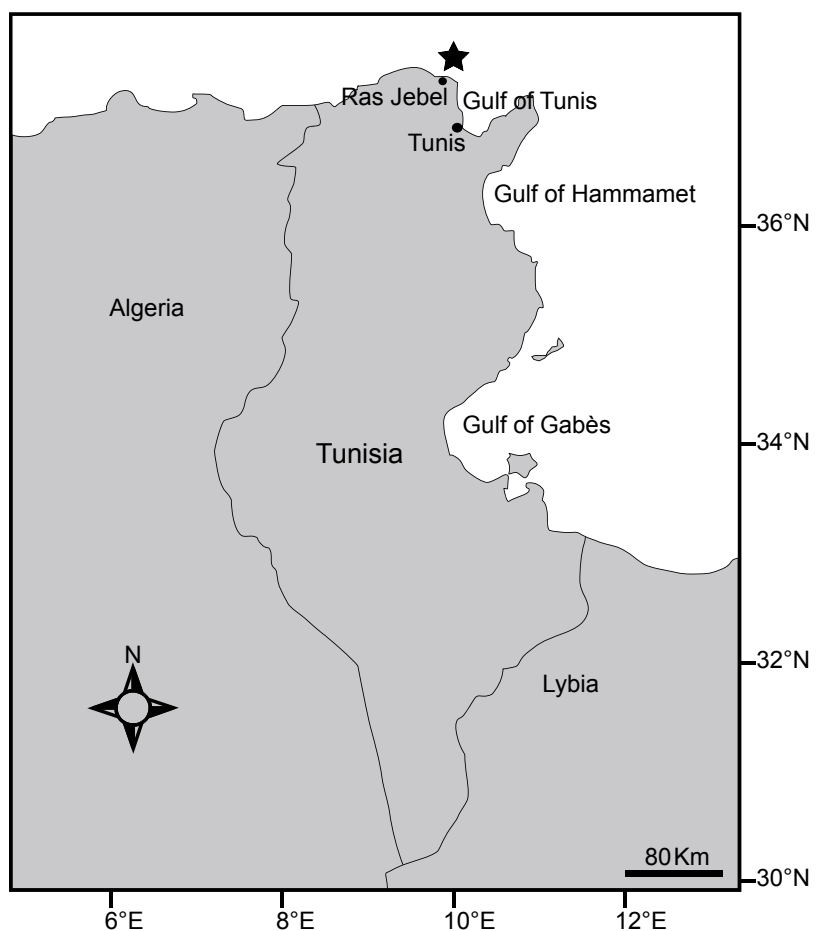

Fig. 1. Map of Tunisia showing the capture sites of Mobula japanica (black stars)

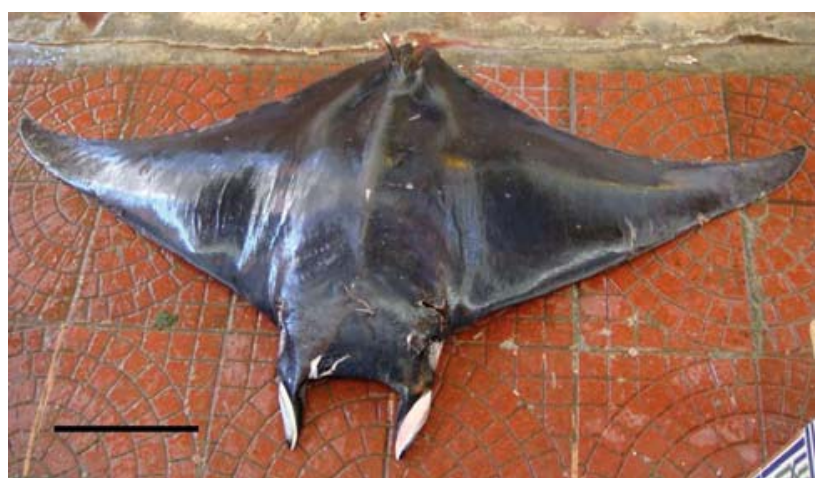

Fig. 2. Female of Mobula japanica (Ref. FSB Mob-jap01) captured from the northern Tunisian coast, with arrow showing white tip on dorsal fin, scale bar $=400 \mathrm{~mm}$

in $22.2 \%-23.1 \%$ and in disc width, and to mouth corner $10.1 \%-11.1 \%$ in disc width, rostral margin rather straight, elliptical spiracles above level of pectoral fins, oval-based stinging spine in base of tail, origin of dorsal fin little in advance of beginning of pelvic fins. Gill filter plates not fused with 18-28 lateral lobes (Fig. 3), terminal lobe leafshaped with longitudinal ridges (Fig. 4). Mouth on ventral surface of head, teeth minute not arranged in rows, but spaced from each other, tooth height larger than crown width (Fig. 5). Denticles dense, minute, shagreen on hinder areas of dorsal surface (Fig. 6). Dorsal surface dark blue with occasional lighter shoulder patches, characteristic white tip on dorsal fin, belly whitish with dark patches, no dark margin anteriorly.

All observations about morphology, colour, morphometric measurements, head proportions and meristic counts are

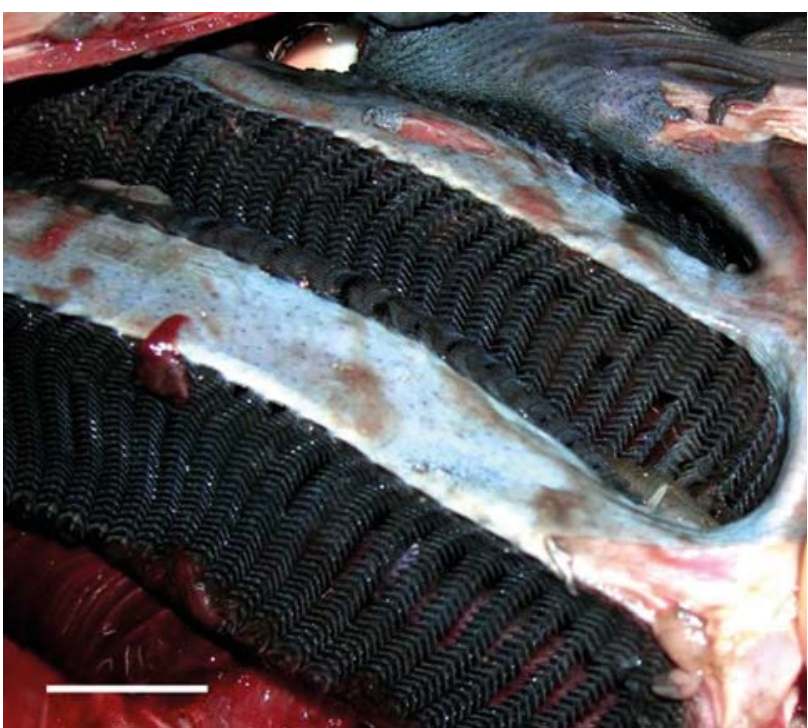

Fig. 3. Gill of Mobula japanica (Ref. FSB Mob-jap 01) captured from the northern Tunisian coast; scale bar = $50 \mathrm{~mm}$

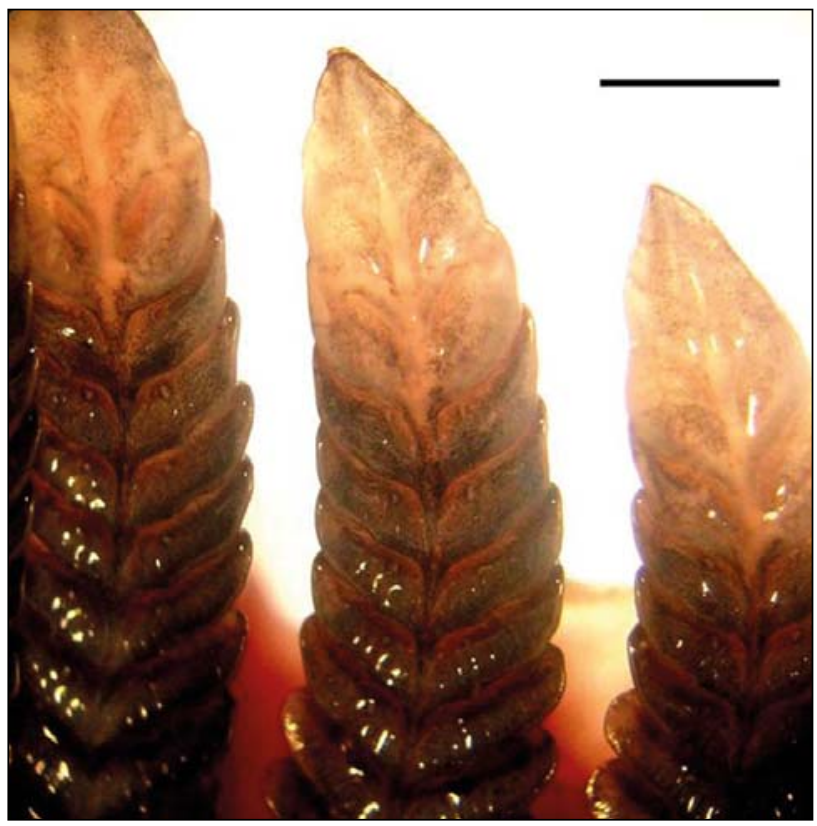

Fig. 4. Mobula japanica (Ref. FSB Mob-jap 01) captured from the northern Tunisian coast; gill filter with leafshaped terminal lobe, exhibiting longitudinal ridges, scale $\mathrm{bar}=3 \mathrm{~mm}$

summarized in Table 1, and are consistent with those provided by Garman (1913), Cadenat $(1959,1960)$, Blache et al. (1970), Notarbartolo Di Sciara (1987), Last and Stevens (1994), Townsend and Kyne (2010), and Bustamante et al. (2012). They allowed to conclude that all collected specimens were spinetail devil rays, Mobula japanica (Müller et Henle, 1841). These occurrences constitute the first well documented records of the species from the Tunisian coast and also, from the entire Mediterranean. Mobula japanica and M. mobular are closely related species, and consequently misidentifications cannot be totally ruled out. The 
Table 1

Measurements carried out in five specimens of Mobula japanica captured from the northern Tunisian coast

\begin{tabular}{|c|c|c|c|c|c|}
\hline Parameter & $\begin{array}{l}\text { FSB-Mob- } \\
\text { jap01 }\end{array}$ & $\begin{array}{l}\text { FSB-Mob- } \\
\text { jap02 }\end{array}$ & $\begin{array}{l}\text { FSB-Mob- } \\
\text { jap03 }\end{array}$ & $\begin{array}{l}\text { FSB-Mob- } \\
\text { jap04 }\end{array}$ & $\begin{array}{c}\text { FSB-Mob- } \\
\text { jap05 }\end{array}$ \\
\hline Sex & Female & Male & Male & Female & Female \\
\hline Disc length & 1200 & - & - & - & 975 \\
\hline Disc width & 2600 & - & - & - & 2180 \\
\hline Cephalic fin length & 270 & 235 & 260 & 240 & 240 \\
\hline Diameter of eye ball & 44 & 44 & 42 & 42 & 43 \\
\hline Cranial width & 400 & 340 & 350 & 355 & 360 \\
\hline Preoral length & 90 & 75 & 80 & 80 & 75 \\
\hline Mouth width & 270 & 225 & 235 & 230 & 240 \\
\hline Internarial distance & 220 & 190 & 190 & 210 & 190 \\
\hline Cephalic fin width & 230 & 130 & 120 & 110 & 120 \\
\hline Width between first gill slit & 260 & 230 & 210 & 230 & 230 \\
\hline Width between second gill slit & 290 & 260 & 230 & 255 & 215 \\
\hline Width between third gill slit & 300 & 255 & 255 & 270 & 210 \\
\hline Width between fourth gill slit & 300 & 260 & 250 & 280 & 240 \\
\hline Width between fifth gill slit & 305 & 260 & 240 & 270 & 250 \\
\hline Pre-first gill slit length & 385 & 340 & 345 & 345 & 350 \\
\hline Pre-second gill slit length & 440 & 380 & 380 & 375 & 380 \\
\hline Pre-third gill slit length & 500 & 420 & 420 & 405 & 420 \\
\hline Pre-fourth gill slit length & 540 & 460 & 460 & 445 & 460 \\
\hline Pre-fifth gill slit length & 600 & 490 & 510 & 483 & 500 \\
\hline Rostrum to 1 st gill openings & 240 & 200 & 210 & 215 & 210 \\
\hline Rostrum to 5 th gill openings & 410 & 350 & 350 & 360 & 340 \\
\hline Distance between cephalic fins tips & 290 & 220 & 25 & 220 & 210 \\
\hline Distance between cephalic fins & 250 & 210 & 230 & 220 & 220 \\
\hline Distance between eyes & 350 & 320 & 325 & 330 & 320 \\
\hline Interspiracular width & 370 & 325 & 330 & 330 & 340 \\
\hline Pre-orbital length & 190 & 170 & 170 & 175 & 175 \\
\hline Pre-spiracle length & 290 & 265 & 270 & 280 & 273 \\
\hline Snout tip to spiracle & 115 & 105 & 100 & 85 & 100 \\
\hline Pre-nostril length & 220 & 190 & 200 & 190 & 190 \\
\hline Snout tip to nostril & 45 & 40 & 42 & 40 & 39 \\
\hline Pre-oral length & 265 & 230 & 235 & 230 & 220 \\
\hline Anterior dorsal fin & 127 & - & - & - & 125 \\
\hline Posterior dorsal fin & 70 & - & - & - & 75 \\
\hline Dorsal fin base length & - & - & - & - & 95 \\
\hline Posterior pectoral fin & - & 1090 & 1160 & 1113 & 1150 \\
\hline Interior pectoral fin & - & 120 & 120 & 100 & 110 \\
\hline Anterior pelvic fin & - & 115 & 140 & 112 & 115 \\
\hline Posterior pelvic fin & - & 53 & 60 & 50 & 50 \\
\hline Interior pelvic fin & - & 92 & 100 & 100 & 95 \\
\hline Clasper & - & 80 & 80 & - & - \\
\hline Eviscerated mass [kg] & 100 & - & - & - & 65 \\
\hline
\end{tabular}

All measurements in mm.

presence in Mediterranean Sea, out of the recent distribution 1. Location of the dorsal fin which is behind the posterior range could be explained (among others) by the absence of margin of the pectoral fins; teeth arranged in rows; abrigorous specific fishery reports of landings, making it dif- sence of a white tip in the dorsal fin ........Mobula mobular ficult to differentiate between mobulid species in the area. 2. Origin of the dorsal fin a little in advance of the beginning

Mobula japanica and M. mobular are large species and of pelvic fins; teeth minute not arranged in rows, but spaced both exhibit a spine on the tail, however they differ by from each other, tooth height larger than crown width; pressome major characters. So, with the addition of $M$. japanica to the Tunisian ichthyofauna, it seems appropriate to present a key allowing to distinguish $M$. mobular from $M$. japanica in the region and the entire Mediterranean:

ence of a white tip in the dorsal fin Mobula japonica

Due to the large body size of spinetail devil rays, only the heads were preserved and deposited in the Ichthyologi- 


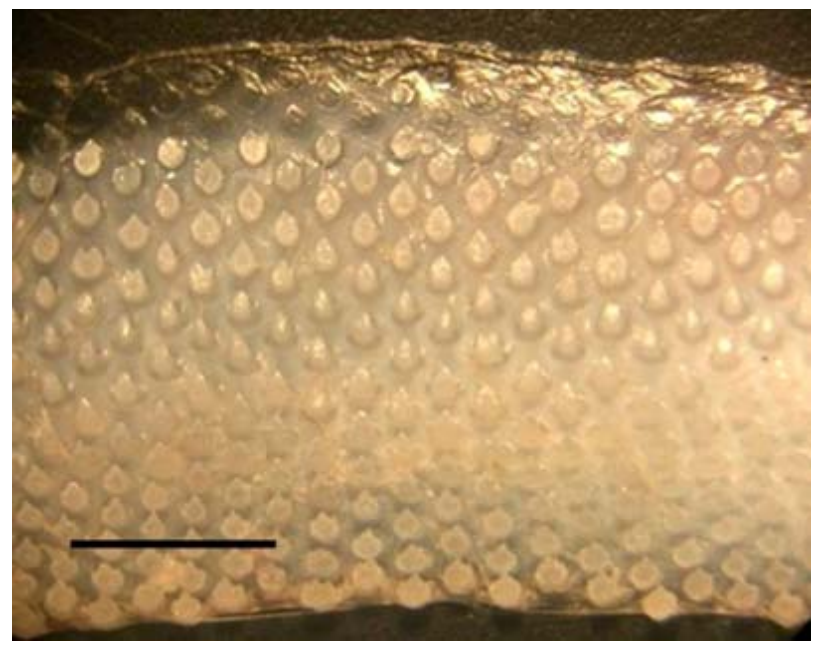

Fig. 5. Mobula japanica (Ref. FSB Mob-jap 01) captured from the northern Tunisian coast; minute teeth arranged in diagonal rows, in a small distance from each other; tooth height exceeding crown width, scale bar $=3 \mathrm{~mm}$

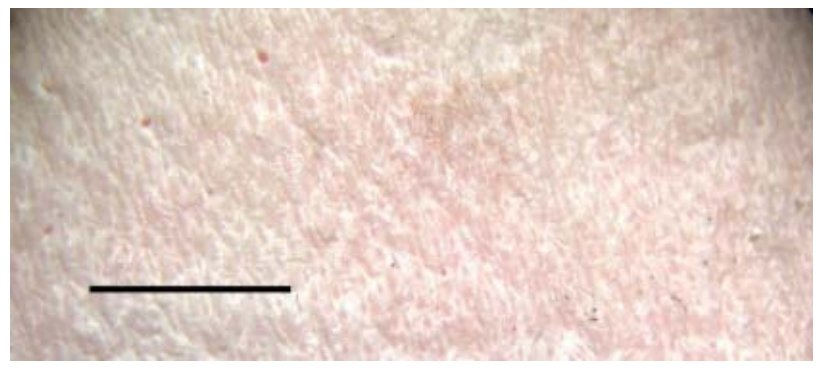

Fig. 6. Skin of Mobula japanica (Ref. FSB Mob-jap 01) captured from the northern Tunisian coast, showing minutes scales ; scale bar $=4 \mathrm{~mm}$

cal Collection of the Faculté des Sciences de Bizerte under the catalogue numbers: FSB-Mob-jap01, FSB-Mob-jap02, FSB-Mob-jap03, FSB-Mob-jap04, and FSB-Mob-jap05.

Mobula japanica is known as a large zooplanktivorous ray widely distributed in tropical to warm temperate waters (Bustamante et al 2012, Couturier et al. 2012). Captures of the species are generally reported in both Pacific and western Atlantic (Bustamante et al. 2012). Previously, the species was described as $M$. rancureli by Cadenat (1959) from specimens caught off the Coast of Ivory, in eastern Atlantic (Cadenat 1960) and probably throughout the Gulf of Guinea (Blache et al. 1970). Mobula rancureli was subsequently considered a junior synonym of $M$. japanica, which consequently occurs off the western coast of Africa (Louisy 2002). Consequently, the records of $M$. japanica presented in this paper are probably due to a migration of the species toward northern areas and entering the Mediterranean Sea through the Strait of Gibraltar, constituting a Herculean migration sensu Quignard and Tomasini (2000). Similar migrations were recently reported off the northern Tunisian coast but they rather concerned teleost species (Azzouz et al. 2011, Ben Souissi et al. 2011, Mansour et al. 2011)

Records of alien species and especially those described in this paper are consistent with data provide by Ben Rais
Lasram and Mouillot (2009) who noted a significant increase of species incoming to the Mediterranean Sea from the Red Sea and eastern tropical Atlantic. Such intrusions are due to the fact that the waters of this sea are becoming warmer for several decades now (Francour et al. 1994, Golani 1998, Dulčić and Grbec 2000, Macias et al. 2013). The new Mediterranean findings of $M$. japanica extend the distribution of the species, and increase the number of fish species in this sea, but also in the Tunisian waters, where captures of 11 specimens showed that the species should considered as locally present, but other records are needed to state if a sustainable population inhabits the area, M. japanica being a large migratory species (Couturier et al. 2012).

\section{ACKNOWLEDGEMENTS}

The authors wish to thank the fishermen from Ras Jebel (Tunisia) on finding and providing the specimens. The kind and hard assistance during the study of Mr Habib Nouira from Ras Jebel is very much appreciated.

\section{REFERENCES}

Azzouz K., Diatta Y., Mansour S., Boumaïza M., Ben Amor M.M., Capapé C. 2011. First record of the west African goatfish, Pseudupeneus prayensis (Actinopterygii: Perciformes: Mullidae), off the Tunisian coast (central Mediterranean). Acta Ichthyologia et Piscatoria 41 (2): 133-136.

DOI: 10.3750/AIP2011.41.2.10

Bello G., Lipej L., Dulčić J. 2012. Comments on a finding of Mobula mobular (Mobulidae) in the Adriatic Sea. Cybium 36 (4): 575-577.

Ben Rais Lasram F., Mouillot D. 2009. Increasing southern invasion enhances congruence between endemic and exotic Mediterranean fish fauna. Biological Invasions 11 (3): 697-711.

DOI: $10.1007 / \mathrm{s} 10530-008-9284-4$

Ben Souissi J., Diatta Y., Gargouri Ben Abdallah L., Capapé C. 2011. Occurrence of the Monrovian surgeonfish Acanthurus monroviae (Osteichthyes: Acanthuridae) off the coast of Tunisia (central Mediterranean). Cahiers de Biologie Marine 52 (3): 331-335.

Blache J., Cadenat J., Stauch A. 1970. Clé de détermination des poissons de mer signalés dans l'Atlantique oriental (entre le 20ième parallèle $\mathrm{N}$ et le 15ième parallèle S). Faune tropicale ORSTOM 18: 1-479.

Bradaï M.N., Capapé C. 2001. Captures du diable de mer, Mobula mobular, dans le golfe de Gabès (Tunisie méridionale, Méditerranée centrale). Cybium 25 (4): 389-391.

Bustamante C., Couturier L.I.E., Bennett M.B. 2012. First record of Mobula japanica (Rajiformes: Myliobatidae) from the south-eastern Pacific Ocean. Marine Biodiversity Records 5: e48.

DOI: $10.1017 / \mathrm{S} 1755267212000310$

Cadenat J. 1959. Notes d'Ichtyologie ouest-africaine, XXV.-Description d'une Mobula de grande taille à aiguillon caudal, de Côte d'Ivoire: Mobula rancureli, sp. nov. Bulletin de l'Institut français d'Afrique noire Série A 21 (4): 1326-1331. 
Cadenat J. 1960. Notes d'Ichtyologie ouest-africaine. XXIX. Les Mobulidae de côte occidentale d'Afrique. Bulletin de 1'Institut français d'Afrique noire Série A 22 (3): 1053-1084.

Capapé C., Bouchereau J.L., Tomasini J.A. 1990. Présence du diable de mer, Mobula mobular (Bonnaterre, 1788) (Pisces, Rajiformes, Mobulidæ) dans le golfe d'Aigues-Mortes. Anatomie de la ceinture pelvienne et des ptérygopodes. Mésogée 50: 9-14.

Capapé C., Zaouali J. 1976. Note sur la présence de la Mante de mer Mobula mobular (Bonnaterre, 1788) (Sélaciens, Rajiformes) dans les eaux tunisiennes. Doriana 5 (223): 1-8.

Couturier L.I.E., Marshall A.D., Jaine F.R.A., Kashiwagi T., Pierce S.J., Townsend K.A., Weeks S.J., Bennett M.B., Richardson A.J. 2012. Biology, ecology and conservation of the Mobulidae. Journal of Fish Biology 80 (5): 1075-1119.

DOI: $10.1111 / \mathrm{j} .1095-8649.2012 .03264 . \mathrm{x}$

Dulčić J., Grbec B. 2000. Climate change and Adriatic ichthyofauna. Fisheries Oceanography 9 (2): 187-191. DOI: $10.1046 /$ j.1365-2419.2000.00128.x

El Kamel O., Mnasri N., Ben Souissi J., Boumaïza M., Ben Amor M.M., Capapé C. 2009. Inventory of elasmobranch species caught in the Lagoon of Bizerte (north-eastern Tunisia, central Mediterranean). Pan-American Journal of Aquatic Sciences 4 (4): 383-412.

Francour P., Boudouresque C.F., Harmelin J.G., Harmelin-Vivien M.L., Quignard J.P. 1994. Are the Mediterranean waters becoming warmer? Information from biological indicators. Marine Pollution Bulletin 28 (9): 523-526.

Garman S. 1913. The Plagiostomia. (Sharks, skates, and rays). Memoirs of the Museum of Comparative Zoölogy at Harvard College 36 (2): 1-528.

DOI: $10.5962 /$ bhl.title.43732

Golani D. 1998. Distribution of Lessepsian migrant fish in the Mediterranean. Italian Journal of Zoology 65 (Suppl. 1): 95-99.

DOI: $10.1080 / 11250009809386801$

Granier J. 1964. Les eusélaciens dans le golfe d'Aigues-Mortes. Bulletin du Muséum d'Histoire naturelle de Marseille 24: 34-52.
Hemida F., Mehezem S., Capapé C. 2002. Captures of the giant devil ray, Mobula mobular (Bonnaterre, 1788) (Chondrichthyes: Mobulidae) off the Algerian coast (southern Mediterranean). Acta Adriatica 43 (2): 69-76.

Last P.R., Stevens J.D. 1994. Sharks and rays of Australia. CSIRO, Melbourne, Australia.

Louisy P. 2002. Guide d'identification des poissons marins Europe et Méditerranée. Ulmer édition, Paris, France.

Macias D., Garcia-Gorriz E., Stips A. 2013. Understanding the causes of recent warming of Mediterranean waters. How much could be attributed to climate change? PLoS ONE 8 (11): e81591. DOI: 10.1371/journal.pone.0081591

Mansour S., Azzouz K., Boumaïza M., Ben Amor M.M., Capapé C. 2011. First record of a rare carnagid species, the Almaco jack, Seriola rivoliana (Osteichthyes: Carangidae) in Tunisian marine waters (central Mediterranean). Cahiers de Biologie Marine 52 (2): 193-202.

McEachran J.D., Capapé C. 1984. Mobulidae. Pp. 210 211. In: Whitehead P.J.P., Bauchot, M.-L., Hureau J.-C., Nielsen J., Tortonese E. (eds.) Fishes of the North-western Atlantic and the Mediterranean. Vol. 1. UNESCO, Paris.

Mejri H., Ben Souissi J., Zaouali J., El Abed A., Guélorget O., Capapé C. 2004. On the recent occurrence of elasmobranch species in a perimediterranean lagoon: the Tunis Southern Lagoon (northern Tunisia). Annales Series Historia Naturalis 14 (2): 143-158.

Notarbartolo Di Sciara G. 1987. A revisionary study of the genus Mobula Rafinesque, 1810 (Chondrichthyes: Mobulidae) with the description of a new species. Zoological Journal of the Linnean Society 91 (1): 1-91. DOI: $10.1111 / \mathrm{j} .1096-3642.1987 . t b 01723 . \mathrm{x}$

Quignard J.-P., Tomasini J.A. 2000. Mediterranean fish biodiversity. Biologia Marina Mediterranea 7: 1-66.

Townsend K.A., Kyne P.M. 2010. New records of the Japanese devilray Mobula japanica (Müller \& Henle 1814) for Australian waters. Memoirs of the Queensland Museum-Nature 55 (1): 225-230.

Received: 2 September 2014 Accepted: 23 December 2014 Published electronically: 30 June 2015 